\title{
PENGARUH MODEL NUMBERED HEAD TOGETHER BERBASIS TRI KAYA PARISUDHA TERHADAP KOMPETENSI PENGETAHUAN IPS SISWA KELAS IV SD
}

\author{
I Putu Wira Dharma ${ }^{1}$, Nyoman Kusmariyatni², Dewa Nyoman Sudana ${ }^{3}$ \\ e-mail : wiradharma07@yahoo.com,nyoman.kusmariyatni@undiksha.ac.id, Dewanyoman.sudana@undiksha.ac.id.
}

\footnotetext{
1 Jurusan Pendidikan Guru Sekolah Dasar, FIP, Universitas Pendidikan Ganesha Singaraja, Indonesia

2 Jurusan Pendidikan Guru Sekolah Dasar, FIP, Universitas Pendidikan Ganesha Singaraja, Indonesia

3 Jurusan Pendidikan Guru Sekolah Dasar, FIP, Universitas Pendidikan Ganesha Singaraja, Indonesia
}

\section{Abstrak}

Penelitian ini bertujuan untuk mengetahui perbedaan yang signifikan kompetensi pengetahuan IPS antara kelompok siswa yang dibelajarkan melalui model pembelajaran Numbered Head Together Berbasis Tri Kaya Parisudha dan kelompok siswa yang dibelajarkan secara konvensional. Jenis penelitian ini adalah quasi experiment dengan desain penelitian menggunakan Non-equivalent post-test Only Control Grup Desain. Populasi penelitian ini adalah seluruh siswa kelas IV SD Gugus IV Kecamatan Sawan Kabupaten Buleleng tahun pelajaran 2018/2019 yang terdiri dari 8 kelas dengan jumlah 165 siswa. Sampel dalam penelitian ini yaitu kelas IV SD Negeri 1 Bungkulan sebagai kelompok eksperimen dan SD Negeri 5 Bungkulan sebagai kelompok kontrol. Pengambilan sampel menggunakan simple random sampling. Data dalam peneltian ini dikumpulkan dengan metode tes dan instrumen tes kompetensi pengetahuan IPS. Data yang diperoleh kemudian dianalisis menggunakan statistik deskriptif dan infrensial (uji-t). Nilai rata-rata yang diperoleh siswa di kelas eksperimen adalah 80,2 termasuk kategori sangat tinggi sedangkan kelompok siswa di kelas kontrol memperoleh nilai rata-rata adalah 73,58 termasuk kategori tinggi. Hasil penelitian menunjukkan bahwa, terdapat perbedaan yang signifikan kompetensi pengetahuan IPS antara kelompok siswa yang dibelajarkan melalui model pembelajaran Numbered Head Together Berbasis Tri Kaya Parisudha dan kelompok siswa yang dibelajarkan secara konvensional. Hasil analisis menggunakan uji-t diperoleh $t_{\text {hitung }}=17,73$ dan $t_{\text {tabel }}=2,021$ sehingga didapatkan $t_{\text {hitung }}>t_{\text {tabel }}$. Dengan demikian, dapat simpulkan model pembelajaran Numbered Head Together Berbasis Tri Kaya Parisudha berpengaruh positif terhadap kompetensi pengetahuan IPS siswa kelas IV SD Gugus IV kecamatan Sawan tahun pelajaran 2018/2019.
\end{abstract}

\section{Keywords:}

Kompetensi pengetahuan IPS,

Numbered Head

Together, Tri Kaya

Parisudha.

\section{PENDAHULUAN}

Pendidikan hal yang sangat penting dalam kehidupan manusia, dengan pendidikan manusia dapat memperoleh berbagai pengetahuan dan dapat mengembangkan kemampuan yang dimiliki untuk dapat diterapkan dan membantu manusia dalam kehidupannya. Arsini (2015) menyatakan bahwa pendidikan merupakan salah satu aspek penting dalam membangun sumber daya manusia (SDM). Pendidikan mempunyai peranan yang sangat besar dalam membentuk kepribadian seorang anak, yang nantinya tumbuh menjadi seorang manusia dewasa dan melakukan banyak interaksi terhadap lingkungannya. Diterapkannya Kurikulum 2013 merupakan salah satu upaya pemerintah dalam memperbaiki sistem dan kualitas pendidikan agar mampu menghasilkan sumber daya manusia yang berkualitas dan mampu bersaing dijaman milineal seperti sekarang ini. Kurikulum 2013 menggunakan pembelajaran tematik terpadu, tematik terpadu disusun berdasarkan gabungan 
beberapa mata pelajaran yang mengaitkan dengan permasalahan-permasalahan yang dijumpai di lingkungan sekitar siswa. Salah satu muatan materi dalam tematik terpadu yaitu Ilmu Pengetahuan Sosial.

Ilmu Pengetahuan Sosial mengajarkan peserta didik agar mampu dalam berinteraksi dan melakukan hubungan sosial di lingkungan sekolah, keluarga maupun lingkungan masyarakat dengan baik. Zuraik (dalam Susanto, 2013:137) Hakikat Ilmu Pengetahuan Sosial (IPS) adalah "Harapan untuk mampu membina suatu masyarakat yang baik dimana para anggotanya benar-benar berkembang sebagai insan sosial yang rasional dan penuh tanggung jawab". Sementara itu Hamalik (dalam Gunawan, 2013:18) mengemukakan bahwa, tujuan pendidikan IPS berorientasi pada tingkah laku para siswa, yaitu (1) pengetahuan dan pemahaman, (2) sikap hidup belajar, (3) nilai-nilai sosial dan sikap, (4) Keterampilan. Dari uraian diatas dapat disimpulkan bahwa, melalui ilmu pengetahuan sosial siswa dapat dibentuk agar memiliki prilaku yang baik untuk menjadi manusia yang memiliki pengetahuan serta keterampilan yang berguna bagi dirinya serta bagi masyarakat dan negara. Dari uraian diatas dapat disimpulkan bahwa, melalui ilmu pengetahuan sosial siswa dapat dibentuk agar memiliki prilaku yang baik untuk menjadi manusia yang memiliki pengetahuan serta keterampilan yang berguna bagi dirinya serta bagi masyarakat dan negara.

Situasi ini tidak sesuai dengan kenyataan di lapangan, penanaman nilai moral dan sikap pada siswa di sekolah selama ini masih kurang optimal, hal tersebut dapat terlihat pada sikap spiritual siswa pada saat melakukan persembahyangan masih banyak siswa menunjukkan sikap yang kurang displin seperti ribut dan bermain. Siswa sering menggunakan kata-kata yang kasar ketika berkomunikasi dengan temannya di lingkungan sekolah, Pada saat proses pembelajaran berlangsung masih ada beberapa siswa yang bermain dan kurang displin dalam mengikuti pembelajaran di kelas, dalam hal inilah peran guru sangat dibutuhkan untuk membimbing peserta didiknya agar memiliki nilai moral dan perilaku yang baik.

Selain itu, guru selaku tenaga pendidik belum sepenuhnya mampu menarik minat siswa untuk mengikuti proses pembelajaran dengan baik, khususnya dalam mata pelajaran IPS. Susanto (2013:155) "masih banyak guru yang melakukan pembelajaran dalam bidang studi IPS dengan menggunakan metode ceramah dan tanya jawab". Pembelajaran IPS di sekolah dasar cenderung didominasi oleh pembelajaran konvensional yang lebih mengandalkan ceramah, guru menjadi pusat informasi dan siswa hanya duduk dan mendengarkan apa yang dikatakan oleh guru tanpa mau mencari infomasi sendiri sehingga keaktifan siswa kurang dan siswa merasa bosan dalam mengikuti pembelajaran, sehingga diperlukan model pembelajaran yang mampu menarik minat siswa untuk mengikuti proses pembelajaran IPS di sekolah.

Berdasarkan hasil observasi yang dilakukan pada tanggal 7 - 11 Januari 2019 di SD Gugus IV Kecamatan Sawan Kabupaten Buleleng bahwa: a) guru masih menggunakan metode ceramah dan penugasan sehingga siswa merasa bosan dan kurang tertarik dalam mengikuti proses pembelajaran. b) Penanaman nilai moral dan sikap kepada peserta didik dalam proses pembelajaran di sekolah belum optimal. c) Nilai siswa dalam kompetensi pengetahuan IPS banyak yang belum mencapai KKM.

Rendahnya kompetensi pengetahuan IPS dipengaruhi oleh beberapa faktor. Salah satu faktor yang sangat penting mempengaruhi adalah Model pembelajaran yang digunakan guru tidak divariasikan dengan model atau metode pembelajaran lainnya. Pemilihan model yang tepat menjadikan siswa dapat terlibat langsung secara penuh dalam proses belajar mengajar serta membuat situasi belajar menjadi kondusif dan tidak menyenangkan. Untuk mengatasi masalah tersebut yaitu dengan memberikan model yang efektif diterapkan agar siswa lebih tertarik dalam mengikuti proses pembelajaran tersebut adalah dengan menggunakan model pembelajaran Tipe Numbered Head Together. 
Model pembelajaran kooperatif terdiri dari berbagai tipe model pembelajaran salah satunya adalah model pembelajaan Numbered Head Together. Menurut Kurniasih \& Sani (2015:29) menyatakan bahwa "Model pembelajaran NHT memiliki ciri khas dimana guru menunjuk seorang siswa untuk mewakili kelompoknya tanpa memberi tahu terlebih dahulu siapa yang akan mewakili kelompoknya tersebut". Cara tersebut merupakan upaya yang sangat baik dilakukan untuk meningkatkan tanggung jawab individual dalam diskusi kelompok yang dilakukan siswa. (Sucidamayanti, 2017:116) menyatakan bahwa "pada model pembelajaran NHT siswa menempati posisi yang sangat dominan dalam proses pembelajaran dan terjadinya kerjasama dalam kelompok dengan ciri utamanya adanya penomoran sehingga semua siswa berusaha untuk memahami setiap materi pelajaran yang diajarkan dan bertanggung jawab atas nomor anggotanya masing-masing".

Sedangkan Shoimin (2014:108) menyatakan bahwa, "Numbered Head Together merupakan suatu model pembelajaran berkelompok yang setiap anggota kelompoknya bertanggung jawab atas tugas kelompoknya, sehingga tidak ada pemisahan antara siswa yang satu dan siswa yang lain dalam satu kelompok untuk saling memberi dan menerima antara satu dengan lainnya". Model pembelajaran Numbered Head Together (NHT), mengutamakan siswa untuk saling bekerja sama dalam kelompok dan bertanggung jawab terhadap hasil kerjanya, dan dapat menumbuhkan keaktifan siswa dalam proses pembelajaran, sehingga siswa akan termotivasi untuk belajar. Menurut Kurniasih (2015:30) setiap model pembelajaran memiliki kelebihan tersendiri begitu juga pembelajaran kooperatif tipe Numbered Head Together (NHT). Kelebihan Numbered Head Together (NHT) yaitu : dapat meningkatkan prestasi belajar siswa, mampu memperdalam pemahaman siswa, melatih tanggung jawab siswa, menyenangkan siswa dalam belajar, mengembangkan rasa ingin tahu siswa, meningkatkan rasa percaya diri siswa, mengembangkan rasa saling memiliki dan kerjasama, setiap siswa termotivasi untuk menguasai materi, menghilangkan kesenjangan antara yang pintar dengan tidak pintar, tercipta suasana gembira dalam belajar.

Dalam upaya meningkatkan kompetensi pengetahuan IPS, perlu dilakukan upaya dengan mengintegrasikan model Numbered Head Together dengan konsep Tri Kaya Parisudha, yang pada dasarnya menekankan nilai-nilai kebaikan yang pada akhirnya mampu melahirkan manusia yang memilki moral dan perilaku yang baik. Subagia dan Wiratma, (2012:42) Menyatakan bahwa "Tri Kaya Parisudha adalah salah satu ajaran agama hindu yang berisikan tentang kebajikan dalam berbuat". Perbuatan yang dimaksud dikelompokkan menjadi tiga yaitu, perbuatan dalam tataran pikiran yang disebut kemampuan berfikir (manacika), perbuatan dalam tataran perkataan yang disebut dengan kemampuan berbicara (wacika), dan perbuatan dalam tataran perilaku atau tingkah laku yang disebut dengan kemampuan berbuat (kayika). Penekanan konsep tersebut dalam pembelajaran IPS akan sangat membantu siswa untuk mengembangkan pengetahuan, pemahaman, dan ketrampilan untuk menyelesaikan masalah sosial yang dialami siswa. Dengan menerapkan konsep Tri Kaya Parisudha dapat melatih siswa untuk berpikir, berkata, dan berbuat yang baik bukan hanya di lingkungan sekolah saja, tetapi harus diterapkan dalam kehidupan sehari-hari. Untuk mengetahui perbedaan yang signifikan kompetensi pengetahuan IPS antara kelompok siswa yang mengikuti pembelajaran dengan model Numbered Head Together Berbasis Tri Kaya Parisudha dan kelompok siswa yang mengikuti pembelajaran secara konvensional pada siswa kelas IV SD Gugus IV Kecamatan Sawan Tahun Pelajaran 2018/2019.

\section{METODE PENELITIAN}

Penelitian ini dilaksanakan di SD Gugus IV Kecamatan Sawan yang terdiri dari 8 SD. Kelompok eksperimen adalah SDN 1 Bungkulan dan kelompok kontrol adalah SDN 5 Bungkulan. Waktu penelitian dilaksanakan pada rentangan semester II (genap) pada bulan April - Mei Tahun Pelajaran 2018/2019. penelitian ini bertujuan untuk mengetahui perbedaan yang signifikan kompetensi pengetahuan IPS antara kelompok siswa yang mengikuti pembelajaran dengan model Numbered Head Together Berbasis Tri Kaya Parisudha dan kelompok siswa yang mengikuti pembelajaran 
secara konvensional pada siswa kelas IV SD Gugus IV Kecamatan Sawan Tahun Pelajaran 2018/2019. variabel bebas model pembelajaran NHT berbasis Tri Kaya Parisudha dan variabel terikat yaitu kompetensi pengetahuan IPS. Penelitian ini merupakan penelitian quasi experiment dengan design menggunakan "Non-equivalent post test only control grup design".Metode pengumpulan data dalam peneltian ini menggunakan metode observasi dan tes kompetensi pengetahuan IPS. Post-test dilakukan pada akhir penelitian setelah diberikan perlakuan untuk mendapatkan perbandingan di kelas eksperimen dan kelas kontrol. Post-test dilakukan pada akhir penelitian setelah diberikan perlakuan untuk mendapatkan perbandingan di kelas eksperimen dan kelas kontrol pada kompetensi pengetahuan IPS. Populasi dalam penelitian ini adalah seluruh siswa kelas IV SD Gugus IV Kecamatan Sawan tahun pelajaran 2018/2019 yang terdiri dari 8 kelas dengan jumlah 165 siswa.

Tabel. 1

Rancangan Non- equivalent post-test Only Control Grup Design

\begin{tabular}{ccc}
\hline Kelompok & Perlakuan & Tes akhir (Post-test) \\
E & $\mathrm{X}_{1}$ & $\mathrm{O}_{1}$ \\
$\mathrm{~K}$ & - & $\mathrm{O}_{2}$ \\
\hline
\end{tabular}

(Dimodifikasi dari Gall,et al dalamAgung, 2014:163)

Sampel dalam penelitian ini adalah 2 kelas, satu kelas eksperimen dan satu kelas kontrol. Pengambilan sampel dalam penelitian ini menggunakan teknik simple random sampling. Sebelum dilakukan penelitian sampel penelitian terlebih dahulu dilakukan uji kesetaraan pada semua sekolah yang ada di gugus IV Kecamatan Sawan. Data yang digunakan dalam uji kesetaraan adalah nilai ulangan akhir (UAS) semester ganjil pada mata pelajaran IPS kelas IV Sekolah Dasar. Uji kesetaraan ini menggunakan analisis Anava A atau anava satu jalur. Setelah dinyatakan setara, kemudian dilakukan random dengan teknik simple random sampling. Teknik ini juga bisa diterjemahkan dengan cara pengambilan sampel berdasarkan Gugus. Sampel yang dirandom dalam penelitian ini adalah kelas, karena tidak mungkin mengubah kelas yang sudah ada. Dari 8 sekolah yang ada di Gugus IV Kecamatan Sawan, dilakukan pengundian untuk mengambil 2 sekolah yang akan dijadikan sampel penelitian. Setelah mengetahui kedua kelompok sampel, selanjutnya dilakukan pengundian untuk menentukan kelas eksperimen dan kontrol. Hasil pengundian diperoleh bahwa kelompok eksperimen yang terpilih adalah SD Negeri 1 Bungkulan. Sedangkan kelompok kontrol yang terpilih adalah SD Negeri 5 Bungkulan. kelas eksperimen diberikan perlakuan dengan menggunakan model Numbered Head Together Berbasis Tri Kaya Parisudha dan kelas kontrol yang tidak diberikan perlakuan model pembelajaran Numbered Head Together Berbasis Tri Kaya Parisudha.

Instrumen yang digunakan dalam penelitian adalah tes. Tes dalam penelitian ini adalah adalah tes kompetensi pengetahuan IPS. Tes yang digunakan adalah tes obyektif dalam bentuk pilihan ganda. Adapun Tes lainnya yang dikembangkan sebagai berikut. (1) menyusun kisi-kisi instrumen (2) membuat butir soal (3) melaukan uji validasi isi (4) uji validitas butir (5) uji reabilitas tes (6) uji tingkat kesukaran (7) uji daya beda tes. Tes tersebut kemudian di ujicoba untuk mencari validitas, reabilitas, taraf kesukaran dan daya beda tes. Sebelum instrumen ini digunakan maka akan diuji validitas, reabilitas, taraf kesukaran dan daya beda tes.

Hasil analisis yang dilakukan oleh judges/ahli setelah dilakukan beberapa kali revisi mengenai tes kompetensi pengetahuan IPS, diperoleh nilai validitas isi sebesar 1,00. Untuk mengklasifikasikan dikategori mana koefisien validitas tersebut, Koefisien validitas isi instrumen kompetensi 
pengetahuan IPS adalah 1,00 yang berarti berada pada rentangan 0,80-1,00 dengan kriteria Validitas sangat tinggi. Selanjutnya hasil uji validitas item instrumen kompetensi pengetahuan IPS, dengan jumlah responden 55 siswa diperoleh 31 butir tes yang valid dari 35 butir tes yang di uji cobakan, dari 31 butir tes yang valid diambil 30 butir tes yang digunakan sebagai post-test. nomor tes yang tidak valid adalah 3,6,16,23.

Kemudian dilakukan uji reabilitas, reliabilitas instrumen kompetensi pengetahuan IPS dihitung dengan bantuan Microsoft Office Exel 2007. Kemudian di peroleh hasil reliabilitas uji coba instrumen sebesar 0,91. Berdasarkan kriteria reliabilitas dapat dikatakan bahwa reliabilitas instrumen kompetensi pengetahuan IPS tergolong sangat tinggi. Taraf kesukaran tes adalah kesulitan tes dipandang dari kemampuan peserta didik untuk menjawab soal artinya tes tersebut akan lebih banyak dapat dijawab benar oleh peserta didik yang pandai dan lebih banyak dijawab salah oleh peserta didik yang bodoh (Koyan, 2011:139). Taraf kesukaran instrumen kompetensi pengetahuan IPS dihitung dengan bantuan Microsoft Office Exel 2007. Diperoleh 1 butir tergolong mudah dan 34 soal tergolong sedang. Jika dihitung secara keseluruhan nilai $\mathrm{P}_{\mathrm{p}}$ sebesar 0,70 yang termasuk dalam kategori sedang, dengan demikian perangkat tes kompetensi penegtahuan IPS memiliki tingkat kesukaran yang baik. Hasil uji daya beda tes diperoleh dengan bantuan Microsoft office Exel 2007 dari 31 butir soal yang valid, dengan daya pembeda berkisar 0,20-0,78 yang mempunyai indeks interpretasi cukup baik, baik dan sangat baik sehingga butir soal tersebut dapat digunakan.

Metode dan teknik Analisis Data dalam penelitian yang dilakukan mengggunakan metode analisis deskriptif dan uji prasyarat analisis. Menurut Agung (2014:110) menjelaskan bahwa "analisis deskriptif adalah suatu cara pengolahan data yang dilakukan dengan jalan menerapkan rumus-rumus statistik deskriptif seperti : distribusi frekuensi, grafik, angka rata-rata (M), median (Md), modus (Mo) dan standar deviasi (SD), untuk menggambarkan suatu objek/variabel tertentu, sehingga diperoleh kesimpulan umum". Setelah itu, dilakukan pengujian prasyarat analisis untuk memperoleh fakta apakah data memenuhi prasyarat homogenitas varians dan normalitas sebaran data. Setelah mendapat data awal tentang kompetensi pengetahuan IPS, kemudian data tersebut diuji normalitas distribusinya untuk mengetahui data kedua kelompok tersebut berdistribusi normalatau tidak. Kriteria pengujian data berdistribusi normal jika $X^{2}$ hitung $<X^{2}$ tabel pada taraf signifikansi $5 \%$ dan derajat kebebasan $\mathrm{dk}=($ Jumlah kelas -1$)$.

Kemudian dilakukan Uji homogenitas varians untuk mencari tingkat kehomogenan yang diambil dari kelompok-kelompok terpisah dari satu populasi yaitu kelompok eksperimen dan kelompok kontrol. Kriteria pengujiannya adalah, jika $F_{\text {hitung }}>F_{\text {tabel }}$ maka varians sampel dalam kelompok berbeda (tidak homogen), jika $\mathrm{F}_{\text {hitung }}<\mathrm{F}_{\text {tabel }}$ maka varians sampel dalam kelompok homogen. Uji homogenitas dilakukan pada taraf signifikansi 5\% dengan derajat kebebasan untuk pembilang $\mathrm{n}_{1}-1$ dan derajat kebebasan untuk penyebut $\mathrm{n}_{2}-1$.

Data yang sudah memenuhi prasyarat, maka selanjutnya dilakukan uji-t dengan menggunakan rumus polled varians. Uji hipotesis digunakan untuk menguji hipotesis yang telah dikemukakan pada penelitian yaitu terdapat perbedaan yang signifikan kompetensi pengetahuan IPS antara kelompok siswa yang mengikuti pembelajaran dengan model Numbered Head Together Berbasis Tri Kaya Parisudha dan kelompok siswa yang mengikuti pembelajaran secara konvensional pada siswa kelas IV SD Gugus IV kecamatan Sawan tahun pelajaran 2018/2019. Kriteria untuk pengujian hipotesis yaitu jika harga $t_{\text {hit }}<t_{\text {tabel, }}$ maka $\mathrm{H}_{0}$ diterima dan $\mathrm{H}_{1}$ ditolak, ini berarti tidak terdapat perbedaan yang signifikan dan jika $\mathrm{t}_{\text {hit }}>\mathrm{t}_{\text {tabel, }}$ maka $\mathrm{H}_{0}$ ditolak dan $\mathrm{H}_{1}$ diterima, ini berarti terdapat perbedaan yang signifikan. Pengujian dilakukan pada taraf signifikansi $5 \%$ dengan derajat kebebasan $d k=n_{1}+n_{2}-$ 2.

\section{HASIL DAN PEMBAHASAN}


Deskripsi data hasil penelitian ini meliputi deskripsi data hasil post-test kelompok siswa yang dibelajarkan dengan model pembelajaran Numbered Head Together Berbasis Tri Kaya Parisudha (eksperimen) dan kelompok siswa yang dibelajarkan secara konvensional (kontrol). Data yang diperoleh dari penelitian ini adalah data Kompetensi Pengetahuan IPS siswa. Jumlah soal post-test kompetensi pengetahauan IPS adalah sebanyak 30 butir dalam bentuk pilihan ganda. Jumlah pertemuan pada masing-masing kelas eksperimen dan kontrol sebanyak 7 kali pertemuan. Rincian data tenang kedua pembelajaran tersebut dianalisis dengan statistik deskriptif yang dihitung secara manual. Deskriptif data kelompok eksperimen dan kelompok kontrol secara umum disajikan pada tabel 2 berikut.

Tabel 2

Rekapitulasi Hasil Perhitungan Kompetensi Pengetahuan IPS

\begin{tabular}{ccc}
\hline Dtatistik & \multicolumn{2}{c}{ Kompetensi Pengetahuan IPS } \\
\cline { 2 - 3 } Mean & $\begin{array}{c}\text { Kelompok } \\
\text { eksperimen }\end{array}$ & $\begin{array}{c}\text { Kelompok } \\
\text { kontrol }\end{array}$ \\
\hline Median & 80,2 & 73,58 \\
\hline Modus & 82,21 & 71,78 \\
\hline Varians & 84,36 & 71,5 \\
\hline Standar Deviasi & 49,7025 & 55.6516 \\
\hline Nilai Minimum & 7,05 & 7,46 \\
\hline Nilai Maximum & 67 & 60 \\
\hline Rentangan & 90 & 87 \\
\hline
\end{tabular}

Hasil perhitungan analisis deskriptif menunjukkan bahwa rata-rata nilai kompetensi pengetahuan IPS yang diperoleh oleh kelompok siswa yang mengikuti pembelajaran dengan model Numbered Head Together Berbasis Tri Kaya Parisudha adalah 80,2 dan rata-rata nilai kompetensi pengetahuan IPS siswa yang mengikuti pembelajaran dengan model konvensional adalah 73,58. Dengan demikian, kompetensi pengetahuan IPS yang mengikuti model pembelajaran Numbered Head Together Berbasis Tri Kaya Parisudha lebih baik dibandingkan dengan siswa yang mengikuti pembelajaran dengan model konvensional.

Berdasarkan uraian deskripsi data kompetensi pengetahuan IPS kelompok eksperimen dan kelompok kontrol dapat ditentukan tinggi rendahnya kualitas varaibel tersebut. Untuk mengetahui tinggi rendahnya kompetensi pengetahuan IPS siswa kelas eksperimen digunakan penilaian skala lima sehingga didapatkan kriteria rata-rata ideal $\left(\mathrm{M}_{\mathrm{i}}\right)$ dan Standar deviasi ideal $\left(\mathrm{SD}_{\mathrm{i}}\right)$. Adapun penentuan tinggi rendahnya kompetensi pengetahuan IPS kelompok eksperimen dan kelompok kontrol dengan menggunakan pedoman konversi skala lima yang dapat disajikan pada tabel 3 berikut. 
Tabel 3

Nilai Absolute Skala Lima dengan Penilaian Acuan Ideal Teoritik

Kompetensi Pengetahuan IPS Kelompok Eksperimen dan kontrol

\begin{tabular}{cc}
\hline Rentangan & Kategori \\
\hline $75 \leq \bar{X} \leq 100$ & Sangat Tinggi \\
\hline $58,33 \leq \bar{X}<75$ & Tinggi \\
\hline $41,67 \leq \bar{X}<58,33$ & Sedang \\
\hline $25 \leq \bar{X}<41,67$ & Rendah \\
\hline $0 \leq \bar{X}<25$ & Sangat Rendah \\
\hline
\end{tabular}

Nilai rata-rata kompetensi pengetahuan IPS kelompok eksperimen dengan menerapkan model pembelajaran Numbered Head Together Berbasis Tri Kaya Parisudha adalah 80,2. Berdasarkan tabel 3 nilai rata-rata kompetensi pengetahuan IPS terletak pada kategori sangat tinggi yang berada pada rentangan $75 \leq X \leq 100$ sedangkan Nilai rata-rata kompetensi pengetahuan IPS kelompok kontrol dengan menerapkan model pembelajaran secara konvensional adalah 73,58. Berdasarkan tabel 3 nilai rata-rata kompetensi pengetahuan IPS terletak pada kategori tinggi yang berada pada rentangan 58,33 $\leq X<75$. Berdasarkan analisis data yang dilakukan dapat disajikan hasil uji normalitas sebaran data kompetensi pengetahuan IPS kelompok eksperimen dan kelompok kontrol pada tabel 4 berikut.

Tabel 4. Hasil Uji Normalitas sebaran data

\begin{tabular}{ccccc}
\hline No & Sampel & $X^{2}$ hitung & $X^{2}$ tabel & Status \\
\hline 1 & Kelompok Eksperimen & 3,1047 & 5,591 & Normal \\
\hline 2 & Kelompok Kontrol & 1,7107 & 5,591 & Normal \\
\hline
\end{tabular}

Berdasarkan perhitungan dengan menggunakan rumus chi-kuadrat, diperoleh $X^{2}$ hitung kompetensi pengetahuan IPS siswa kelompok eksperimen adalah 3,1047 dan $X^{2}$ tabel $=5,591$ pada taraf signifikansi $5 \%$ dan db $=5-2-1=2$. Hal ini berarti, $X^{2}$ hitung hasil post-test kompetensi pengetahuan IPS siswa kelompok eksperimen lebih kecil dari $X^{2}$ tabel $\left(X^{2}{ }_{\text {hitung }}<X^{2}\right.$ tabel $)$ sehingga data kompetensi pengetahuan IPS siswa kelompok eksperimen berdistribusi normal. Sedangkan $X^{2}$ hitung kompetensi pengetahuan IPS siswa kelompok kontrol adalah 1,7107 dan $X^{2}$ tabel $=5,591$ pada taraf signifikansi 5\% dan $\mathrm{db}=5-2-1=2$. Hal ini berarti, $X^{2}$ hitung hasil post-test kompetensi pengetahuan IPS siswa kelompok kontrol lebih kecil dari $X^{2}$ tabel $\left(X^{2}\right.$ hitung $<X^{2}$ tabel $)$ sehingga data kompetensi pengetahuan IPS siswa kelompok kontrol berdistribusi normal.

Pada penelitian ini, uji homogenitas dilakukan terhadap varians antar kelompok eksperimen dan kontrol. Untuk menguji homogenitas varians terhadap dua sampel dapat dilakukan dengan menggunakan uji $\mathrm{F}$, dengan kriteria data homogen jika $\mathrm{F}_{\text {hitung }}<\mathrm{F}_{\text {tabel. }}$ Ringkasan hasil uji homogenitas varians antar kelompok eksperimen dan kontrol disajikan pada Tabel 5.

Tabel 5. Hasil Analisis Homogenitas Varians 


\begin{tabular}{llll}
\hline Sumber Data & $\mathrm{F}_{\text {hitung }}$ & $\mathrm{F}_{\text {tabel }}$ & Keterangan \\
\hline $\begin{array}{l}\text { Post test kelompok } \\
\text { eksperimen dan kontrol }\end{array}$ & 1,12 & 2,16 & Homogen \\
\hline
\end{tabular}

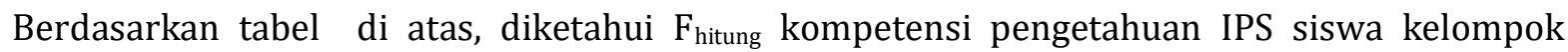
eksperimen dan kontrol dengan db pembilang $=19-1=18$ dan db penyebut $=20-1=19$ pada taraf signifikansi $5 \%$ diketahui $\mathrm{F}_{\text {hitung }}=1,12$ dan $\mathrm{F}_{\text {tabel }}=2,16 \mathrm{Hal}$ ini berarti bahwa $\mathrm{F}_{\text {hitung }}<\mathrm{F}_{\text {tabel }}$ sehingga data kompetensi pengetahuan IPS siswa bersifat homogen.

Pengujian hipotesis penelitian dilakukan dengan menggunakan uji-t dengan rumus polled varians, karena jumlah sampel kelompok eksperimen dan kontrol tidak sama $\left(n_{1} \neq n_{2}\right)$ dan varians homogen. Dengan ketentuan jika $t_{\text {hit }}<t_{\text {tabel, }}$ maka $H_{0}$ diterima dan jika $t_{\text {hit }}>t_{\text {tabel, }}$ maka $H_{0}$ ditolak dengan taraf signifikansi $5 \%$ dengan $d k=\left(n_{1}+n_{2}\right)-2$.

Tabel 6. Hasil Analisis Uji-t

\begin{tabular}{lcccccc}
\hline $\begin{array}{l}\text { Sampel } \\
\text { Penelitian }\end{array}$ & $\mathrm{N}$ & $\bar{X}$ & $\mathrm{dk}$ & $\mathrm{S}^{2}$ & $\mathrm{t}_{\text {hitung }}$ & $\mathrm{t}_{\text {tabel }}$ \\
\cline { 1 - 5 } Eksperimen & 20 & 80,2 & 37 & 49,7025 & \multirow{2}{*}{17,73} & 2,021 \\
\cline { 1 - 3 } Kontrol & 19 & 73,58 & 37 & 55,6516 & & \\
\hline
\end{tabular}

Berdasarkan hasil perhitungan, $t_{\text {hitung }}$ diperoleh 17,73 pada taraf signifikansi $5 \%$ dengan $\mathrm{dk}=$ $(20+19)-2=37$ sehingga $t_{\text {tabel }}$ sebesar 2,021 sehingga diketahui $t_{\text {hitung }}>t_{\text {tabel }}(17,73>2,021)$. Kriteria untuk pengujian hipotesis tersebut adalah $\mathrm{H}_{0}$ ditolak dan $\mathrm{H}_{1}$ diterima, maka dapat diartikan terdapat perbedaan yang signifikan kompetensi pengetahuan IPS siswa antara kelompok siswa yang mengikuti pembelajaran dengan model Numbered Head Together Berbasis Tri Kaya Parisudha dan kelompok siswa yang mengikuti pembelajaran secara konvensional pada siswa kelas IV SD Gugus IV kecamatan Sawan tahun pelajaran 2018/2019.

Adanya perbedaan kompetensi pengetahuan IPS tersebut disebabkan karena perbedaan perlakuan yang diberikan pada pelaksanaan pembelajaran. Berdasarkan penelitian yang telah dilakukan pada proses pembelajaran di kelas eksperimen, pembelajaran dengan model Numbered Head Together Berbasis Tri Kaya Parisudha lebih menekankan aktifitas siswa untuk memperoleh informasi mengenai materi pembelajaran melalui diskusi dengan anggota kelompoknya, siswa mampu melaporkan hasil informasi di depan kelas dengan baik dan benar sehingga siswa lebih antusias dan lebih banyak mendominasi kegiatan pembelajaran (student centered). Adapun tahapantahapan di dalam pelaksannanya model ini, yaitu sebagai berikut. Sebelum kegiatan pembelajaran dimulai guru bersama siswa berdoa menurut kepercayaan masing-masing, melakukan perbuatan baik dengan melakukan doa sebelum pembelajaran (Kayika). setelah itu guru menyampaikan tujuan pembelajaran, sehingga siswa mengetahui apa yang harus dicapai di dalam pembelajaran.

Tahap selanjutnya yaitu penomoran. Dalam tahap ini guru membagi siswa ke dalam kelompok yang terdiri dari 3-5 orang, setiap siswa dalam satu kelompok memiliki nomor yang berbeda. Selanjutnya guru mengarahkan siswa untuk duduk bersama anggota kelompoknya dengan sikap yang tertib (Kayika) dan melakukan interaksi yang baik dalam kelompok dengan bahasa yang sopan dan santun (Wacika). Tahap selanjutnya mengajukan pertanyaan. Pada tahap ini, guru memberi arahan kepada siswa untuk membaca bukunya sekaligus memahami materi tersebut. Dalam proses memahami materi, apabila ada yang kurang di pahami bisa ditanyakan kepada guru. Setelah siswa selesai membaca bukunya, siswa di suruh untuk menutup bukunya, kemudian guru memberikan LKPD kepada siswa sebagai bahan diskusi. (Kayika). 
Selanjutnya tahap berpikir bersama. Pada tahap ini, siswa mendiskusikan pertanyaan yang diberikan oleh guru, dalam kelompok, setiap siswa berfikir bersama mengenai masalah yang diberikan dan masing-masing siswa harus mengetahui jawaban dari permasalahan yang diberikan. Siswa melakukan interaksi, semua siswa terlihat aktif, melakukan diskusi dengan baik, dan kerjasama antar siswa sangat kompak selama diskusi (Kayika), hal ini diwujudkan melalui sikap saling menghargai yang dimiliki siswa (Manacika). Selanjutnya tahap menjawab pertanyaan. Pada tahap ini, guru memanggil suatu nomor tertentu, kemudian siswa yang nomornya sesuai mengacungkan tangannya dan mencoba untuk menjawab pertanyaan untuk seluruh kelas.

Setelah itu guru memberikan kesempatan kelompok lain untuk berkomentar. Masingmasing siswa dalam kelompok mempersiapkan diri untuk menjawab pertanyaan. Bagi siswa yang nomornya dipanggil akan menuliskan jawabanya di depan kelas. Setelah semua pertanyaan selesai dijawab guru bersama siswa menyimpulkan jawaban akhir dari semua pertanyaan. Pendapat tersebut sejalan dengan pendapat Kurniasih \& Sani yang menyatakan bahwa model pembelajaran NHT memiliki ciri khas dimana guru menunjuk seorang siswa untuk mewakili kelompoknya tanpa memberi tahu terlebih dahulu siapa yang akan mewakili kelompoknya tersebut. Cara tersebut merupakan upaya yang sangat baik dilakukan untuk meningkatkan tanggung jawab individual dalam diskusi kelompok yang dilakukan siswa.

Dalam tahap menjawab pertanyaan ini, siswa diarahkan oleh guru untuk selalu berkata yang sopan dan santun sesuai dengan nilai dan norma yang berlaku dan menggunakan bahasa yang mudah dimengerti oleh siswa lainnya (Wacika). Selain itu siswa juga diarahkan untuk selalu menghargai pendapat teman dalam diskusi (Kayika). Dalam menggunakan Model pembelajaran Numbered Head Together yang dipadukan dengan ajaran Tri Kaya Parisudha. Ajaran Tri Kaya Parisudha juga dapat diartikan sebagai tiga dasar perbuatan manusia yang harus disucikan, yaitu manacika, wacika, dan kayika. Manacika artinya berpikir yang baik, Wacika berkata yang baik, dan Kayika artinya berbuat yang baik dinyatakan Parisadha (dalam Astawan, 39:2018). Menurut Rosalina (2017:224) Konsep Tri Kaya Parisudha meliputi 'pikiran' (Manacika), 'perkataan' (Wacika), dan 'perbuatan' (Kayika), dipercaya dapat menghasilkan energi intelektual, emosional, spiritual dan energi kreatif.

Selain langkah-langkah pembelajaran, perbedaan yang signifikan kompetensi pengetahuan IPS juga disebabkan oleh beberapa hal yaitu motivasi belajar, aktifitas siswa, adanya interaksi yang baik antar siswa dan memiliki sikap tanggung jawab yang tinggi saat proses pembelajaran berlangsung. Siswa pada saat diberikan perlakuan berupa model Numbered Head Together Berbasis Tri Kaya Parisudha menjadikan siswa lebih bersemangat untuk belajar dan termotivasi untuk mengerjakan tugas-tugas yang diberikan oleh guru serta tidak merasa bosan lagi ketika belajar IPS. Selain itu sikap siswa ketika diskusi dilakukan, siswa menggunakan bahasa yang sopan dan bersikap yang ramah terhadap seluruh siswa dan guru sehingga memperoleh hasil belajar yang maksimal. Pada pembelajaran model Numbered Head Together Berbasis Tri Kaya Parisudha interaksi siswa sangat baik. Hal ini terlihat dari interaksi yang terjadi antara siswa yang satu dengan lainnya maup un saat siswa melakukan diskusi, sehingga menciptakan suasana belajar yang menyenangkan dan tertib. Selain itu siswa yang pintar dalam kelompok akan membimbing dan memotivasi temannya yang kurang mampu untuk memecahkan suatu permasalahan agar seluruh anggota kelompoknya mampu menyampaikan hasil diskusi dengan baik ketika ditunjuk guru.

Dengan pembentukan kelompok ini siswa mampu berinteraksi dan saling bertukar pikiran dengan teman kelompoknya, sehingga siswa mampu menghargai perbedaan pendapat saat melakukan diskusi. Hal senada juga dinyatakan oleh Sucidamayanti (2017) mendifinisikan dalam penerapan model pembelajaran kooperatif, siswa juga dapat mengemukakan pemikirannya, saling bertukar pendapat dan saling bekerja sama jika ada teman dalam kelompoknya yang mengalami kesulitan. Dalam pembelajaran mengunakan model Numbered Head Together Berbasis Tri Kaya Parisudha aktivitas siswa menjadi meningkat. Aktivitas siswa sangat diutamakan dalam pembelajaran ini, pada saat guru menunjuk salah satu nomor, siswa awalnya terlihat gugup namun 
setelah diberikan motivasi kepada siswa berupa pujian dari guru dan memberikan tepuk tangan yang meriah kepada siswa yang mampu menjawab pertanyaan, siswa yang awalnya takut dan gugup berbicara perlahan-lahan mulai berani, sehingga terlihat semua siswa aktif untuk mengikuti pembelajaran. Selain itu, kegiatan pembelajaran yang menyenangkan membuat siswa tidak merasa tegang sehingga siswa menjadi terbiasa mengangkat tangan untuk bertanya dengan menggunakan bahasa yang sopan apabila kurang mengerti dan siswa lebih berani mengungkapkan pendapatnya. Hal inilah yang membuat siswa tidak merasa takut maupun malu ketika berbicara di hadapan guru maupun teman-temannya. Dampak positif yang ditumbulkan dari hal tersebut yaitu tumbuhnya rasa percaya diri siswa ketika berinteraksi dengan orang lain.

Pembelajaran dengan model Numbered Head Together Berbasis Tri Kaya Parisudha meningkatkan rasa tanggung jawab siswa dalam kelompok maupun individu. Dalam kelompok siswa bertanggung jawab dalam mengerjakan tugas-tugas yang diberikan guru. Hal ini dibuktikan dengan siswa bersungguh-sungguh dalam berdiskusi, untuk mengerjakan tugas yang diberikan oleh guru. Setiap siswa harus bertanggung jawab terhadap nomor yang dimilikinya, pada saat guru memanggil salah satu nomor siswa secara acak untuk menjawab pertanyaan sesuai dengan kemampuan dan hasil diskusi yang dilakukan dengan kelompoknya. Dengan memanggil salah satu nomor siswa secara acak, cara tersebut merupakan upaya yang sangat baik dilakukan untuk meningkatkan tanggung jawab individual dalam diskusi kelompok yang dilakukan siswa. Siswa menjadi lebih termotivasi untuk belajar dan berusaha memahami tugas yang dikerjakan agar bisa menjawab saat di panggil karena setiap jawaban tidak hanya mempengaruhi nilai individunya namun juga mempengaruhi nilai kelompoknya sehingga siswa akan berusaha untuk menyampaikan hasil diskusi kelompoknya dengan baik dan benar. Hal ini di dukung oleh pendapat Shoimin (2014) menyatakan bahwa, Numbered Head Together merupakan suatu model pembelajaran berkelompok yang setiap anggota kelompoknya bertanggung jawab atas tugas kelompoknya, sehingga tidak ada pemisahan antara siswa yang satu dan siswa yang lain dalam satu kelompok untuk saling memberi dan menerima antara satu dengan lainnya. Dari pemaparan diatas dapat disimpulkan bahwa, model pembelajaran Numbered Head Together Berbasis Tri Kaya Parisudha adalah salah satu model yang menekankan aktivitas siswa bersama kelompok dalam memecahkan permasalahan melalui diskusi kelompok, dimana semua siswa bertanggung jawab dan berperan aktif terhadap kelompoknya, sehingga akan berpengaruh postif dapat meningkatkan pemahaman dan kompetensi pengetahuan IPS siswa.

Dalam pelaksanaanya model Numbered Head Together Berbasis Tri Kaya Parisudha tidak memerlukan modal atau biaya yang terlalu tinggi, karena hanya membutuhkan ikat kepala yang bisa dibuat dengan kertas karton, yang digunakan sebagai identitas siswa yang berupa nomor kepala. Selain itu hambatan yang ditemukan dalam pelaksanaan model ini yang dilakukan di kelas eksperimen adalah masih ada 2-3 siswa yang bercanda atau kurang disiplin ketika melakukan diskusi kelompok, dengan hal itu guru langsung membimbing dan menasehatinya.

Temuan Hasil penelitian diatas sejalan dengan hasil penelitian yang dilakukan oleh Juniarta (2016), menyatakan bahwa penggunaan model pembelajaran NHT mampu meningkatkan kompetensi pengetahuan IPS siswa. Hal ini dapat dilihat dari analisis data, diperoleh $t_{\text {hitung }}\left(t_{\text {hitung }}=4,230>2,000\right.$ ) dengan dk 92 dan taraf signifikansi 5\%. Dari hasil penelitian tersebut menunjukkan bahwa penguasaan kompetensi pengetahuan IPS berpengaruh antara siswa yang mengikuti Model Pembelajaran Numbered Head Together Berbasis Pendekatan Saintifik dengan siswa yang mengikuti model pembelajaran konvensional, dan berdasarkan nilai rata-rata kelompok eksperimen $X=71,73$ $>X=63,59$ pada kelompok kontrol.

Berbeda halnya dengan siswa yang mengikuti model pembelajaran secara konvensional. Dalam pembelajaran konvensional, guru lebih mendominasi proses pembelajaran, guru menjelaskan materi secara detail dengan menggunakan metode ceramah, sedangkan siswa hanya bertugas mendengar, mencatat, dan menghafal materi yang disampaikan oleh guru sehingga siswa cenderung pasif dalam menggali informasi. Kebanyakan siswa kurang memperhatikan penjelasan guru, ada 
siswa yang bermain dan ribut dengan teman sebangkunya. Kondisi demikian tidak memberikan ruang bagi siswa untuk mengembangkan pengetahuan dan potensi yang dimilikinya. Keadaan seperti ini yang membuat siswa merasa bosan dan jenuh dalam belajar, akibatnya pemahaman dan daya ingat siswa terhadap materi masih kurang. Hal ini yang menyebabkan rendahnya kompetensi pengetahuan IPS siswa. Hal tersebut terlihat dari kompetensi pengetahuan IPS siswa di kelompok kontrol lebih rendah dibandingkan kelompok eksperimen.

\section{SIMPULAN DAN SARAN}

Berdasarkan hasil penelitian dan pembahasan, maka dapat disimpulkan bahwa terdapat perbedaan yang signifikan kompetensi pengetahuan IPS antara kelompok siswa yang mengikuti pembelajaran dengan model Numbered Head Together Berbasis Tri Kaya Parisudha dan kelompok siswa yang mengikuti pembelajaran secara konvensional pada siswa kelas IV SD Gugus IV kecamatan Sawan tahun pelajaran 2018/2019. Hasil tersebut dapat diperoleh dari perhitungan uji-t dengan $t_{\text {hitung }}$ sebesar 17,73 dan $t_{\text {tabel }}=2,021$ dengan taraf signifikansi $5 \%$ dan $d b=(20+19-2)=37$, sehingga $\mathrm{H}_{0}$ ditolak dan $\mathrm{H}_{\mathrm{a}}$ diterima. Dari rata-rata $(X)$, diketahui rata-rata kelompok eksperimen sebesar 80,2 dan rata-rata kelompok kontrol sebesar 73,53. Hal ini berarti $(X)$ eskperimen $>(X)$ kontrol. Dengan demikian dapat disimpulkan bahwa model pembelajaran Numbered Head Together Berbasis Tri Kaya Parisudha berpengaruh terhadap kompetensi pengetahuan IPS siswa kelas IV SD Gugus IV Kecamatan Sawan tahun pelajaran 2018/2019.

Adapun beberapa saran yang dapat disampaikan, dari hasil penelitian yang telah dilakukan adalah sebagai berikut. (1) Kepada siswa disarankan untuk selalu aktif dalam proses pembelajaran artinya apabila kurang memahami materi yang dijelaskan segera ditanyakan kepada guru, tertib dan mendengarkan penjelasan guru dengan baik agar mencapai hasil belajar yang maksimal. (2) Kepada guru disarankan untuk menggunakan model pembelajaran yang inovatif. Salah satunya adalah dengan menggunakan model pembelajaran Numbered Head Together Berbasis Tri Kaya Parisudha pada mata pelajaran IPS, mengingat hasil dari penelitian ini dengan menggunakan model pembelajaran tersebut dapat meningkatkan keaktifan siswa, siswa lebih tertarik dalam mengikuti proses pembelajaran dan meningkatkan kompetensi pengetahuan IPS. (3) Kepada kepala sekolah disarankan untuk memberikan motivasi kepada guru-guru dalam menggunakan model pembelajaran Numbered Head Together Berbasis Tri Kaya Parisudha dan model inovatif lainnya. (4) Kepada peneliti lain disarankan untuk menggunakan penelitian ini sebagai acuan dalam mengadakan penelitian selanjutnya terhadap mata pelajaran atau kompetensi lainnya.

\section{UCAPAN TERIMAKASIH}

Ucapan terimakasih kepada seluruh pihak yang telah membantu terselesaikannya penelitian ini. Terimakasih juga disampaikan kepada pimpinan redaksi Mimbar PGSD Undiksha dan juga google cendikiawan atas kesediannya menerbitkan jurnal ini. 


\section{DAFTAR RUJUKAN}

Arsini, N. N. 2015. " Pengaruh Model Pembelajaran Kooperatif Tipe Numbered Head Together (NHT) Terhadap Hasil Belajar IPS Siswa Kelas IV Semester II Gugus VI Kecamatan Kintamani Tahun Pelajaran 2014/2015”. e-journal PGSD Universitas Pendidikan Ganesha. Volume 3 Nomor 1 (hal 1 - 10).

Astawan, I.G. 2018. Model Pembelajaran Tri Kaya Parisudha di Sekolah Dasar. Singaraja: Undiksha Press.

Juniarta, D.G. 2016. " Pengaruh Model Numbered Head Together Berbasis Pendekatan Saintifik Terhadap Penguasaan Kompetensi Pengetahuan IPS Siswa Kelas V SD Gugus Mayor Metra Denpasar Tahun Ajaran 2015/2016". e-journal PGSD Universitas Pendidikan Ganesha.Volume 4 Nomor 1(hal 1 - 11).

Kurniasih Imas \& Sani Berlin 2015 Ragam Pengembangan Model Pembelajaran Untuk Peningkatan Profesionalitas Guru. Yogyakarta: Kata Pena.

Rosalina, P.D.2017 “The Implementation Of Hindu Philosopy Tri Kaya Parisudha For Sustainable Tourism In Munduk Village North Bali" : STPBI Volume 3 Nomor 2 (Hal 224).

Sucidamayanti, N.P.W. 2017. "Penerapan Model Pembelajaran Kooperatif Tipe Numbered Head Together Untuk Meningkatkan Hasil belajar IPS". International Journal of Elementary Education. Volume 1(1) (hal - 10).

Subagia, I. W. \& Wiratma, I.G.L. 2012 "Taksonomi Pembelajaran Dan Penilaian Hasil Belajar Berbasis TriKaya" Jurnal Pendidikan Indonesia.Volume 1 Nomor 1 (halaman 40-64).

Susanto. A. 2013. Teori belajar \& Pembelajaran di sekolah Dasar. Rawamangun: kencana prenadamedia group.

Shoimin, A. 2014. 68 Model Pembelajaran Inovatif dalam kurikulum 2013.Yogyakarta: Ar-Ruzz Media. 